\title{
Environmental Problems and the Question of Intergenerational Justice from the Kantian Perspective
}

\author{
Timothy Adie OKPE ${ }^{1}$, Samuel Akpan BASSEY ${ }^{\mathbf{1}}$ \\ ${ }^{1}$ Department of Philosophy, University of Calabar, Calabar, Cross River, 540242, Nigeria \\ samuelbassey15@yahoo.com
}

\begin{abstract}
In this paper, I aim at unraveling some of the numerous environmental practices in Nigeria that often times leads to environmental degradation which to a larger extent affects us presently and the effect on the future generation is better imagined if positive actions are not taken to check this trend. It is on the basis of this using one of Kant's categorical imperative that states that "we should act only on that maxim that you can will as a universal law" will be used as the main focus of this paper to bring to bear or light that, we actually owe the future generation the duty to conserve the environment for them. This work argues that we should be careful and considerate with the way we treat the environment through our actions because if the generation before ours had abuse and degrade the environment the way we are doing, our present generation would not have had a beginning. It is my humble submission that this can be achieved through radical exposure to the harm done on the ecosystem by this present generation and a radical awareness that will be taken to the very foundation of our grass root. It is only just and fair that this present generation stop the misuse of the environment. This justice if pursued will go ahead to preserve and conserve the environment for the future generation. The method used basically is systematic analysis, expository, argumentative and critical thinking to enable me make valid and acceptable judgment.
\end{abstract}

Keywords: Pollution; Deforestation; Erosion; Ozone Layer Depletion; Bush Burning

\section{Introduction}

Through human activities, life on earth faces serious danger of extermination. Since the dawn of modernity, humans has been sequentially polluting, degrading and destroying the very environment which sustain their life and that of other living organism found in the ecosystem. Not only has man succeeded in making the environment hostile to life, he has also turn it into a breeding ground for usual and unusual diseases and sickness.

The air is polluted and scientists says that, the entire atmosphere is engulfed in a nebulous mass of pollution formed by tons of poisonous substances and gases emitted from garbage dumps, vehicles, industries, from agricultural plants as well as from household use of insecticides.

As if this is not threatening enough there have been periodic and accidental release of toxic wastes from nuclear plants into the atmosphere and these in turn combine with other dangerous emission mentioned above to deplete the ozone layer.

There is as well increase in water pollution. Tons of contaminants from industries, irresponsible dumping of toxic waste and nitrates gain access into groundwater, streams and 
river on hourly and daily basis. Also, through senseless, reckless and irresponsible action of oil companies in exploration of crude oil which in most cases does not follow the best practices often leads to oil spillage in the oil producing areas and this pollute the water killing all the aquatic life found in the water and it also increases cases of water borne diseases such as cholera, diarrhea, typhoid etc

Through deforestation, bush burning, overgrazing, road construction and poor drainage system, humans initiates erosion which sweep away farmland and devastates roads and landscapes as much as they lead to desertification. With the increase of air, water, land pollution and other human activities, our environment becomes progressively hostile to life in general.

A major ecological crisis that concerns the future generation is the over exploitation and exhaustion of natural resources. Some of us have been very concerned about the ecological irresponsibility and greed typical of the present generation. Considering that materials, metals and raw materials are limited, there is a well founded fear that it would not be long for them to be totally exhausted if this generation continue to exploit the resources at the pace they are going given the fact that, such mineral resources accumulated in the course of millions of years.

This present generation is not even considering whether the future generation would be left with any means of sustenance and this is where Kant's categorical imperative maxim which states that "act only on that maxim that you can will as a universal law comes to mind". This maxim in relating it to this work simply means; if the present generation irresponsibility and greed towards the environment becomes a norm or law, hopefully, will they be comfortable with it? if not, they should change their attitude and actions towards the environment.

\section{Review of Literature}

\subsection{Nature Of Environmental Degradation In Nigeria}

The term environment has been defined and interpreted in many ways. FEPA Act of 1992 (Federal Environmental Protection Agency) under section 88 gave a wide definition of the environment. Environment according to this act includes water, air, land and all plants and animal living therein and the inter-relationship which exist among them. (Gazette extraordinary No. 73. No. 179). What this definition of the environment means is that, the environment comprises of the physical structures as well as the totality of space and the sociocultural setting inherent in this space called environment.

Hagget defined the environment as the sum total of all conditions that surround man at any point in time on the earth's surface $(1995,3)$. This means that, the environment consists of air, land, water, plants and animal life including man's socio-cultural and economic conditions that influences the life of man or the community, any building structure, machine or other devices made by man. It also include any solid, liquid, gas, odour, heat, vibration or radiation resulting directly or indirectly from the activities of man and finally, any part or combination of the foregoing the inter-relationship between any two or more of them.

To buttress this definition, Abraham defined the environment as the sum total of all external conditions influencing the growth and development of the ecosystem and this includes the physical biological, social and cultural factors (249). By this definition, the environment is the aggregate of all the external conditions that influences and affects the life 
and development of both living and non-living entities found in the ecosystem. It is where biotic component are interacting with non-biotic components, that is, where living (man) as a unit within the ecosystem interacts with and is dependent on other living things as well as the physical, chemical and socio-cultural factors in the ecosystem. The physical component of the environment are the natural resources in which man's socio-economic development depends.

In respect of the above, Nicholson in his book titled "The New Environmental Age" said that man's seemingly unlimited power to dominate his environment and exploit physical (natural resources) therein for selfish needs, greed as well as desires has obscured his appreciation of the fact that man is but a unit, a part of a comprehensive system of dynamic inter-dependences that is more than the sum of its part (125). This means that, man's activities is adversely affecting the environment and directly or indirectly, it is having negative effect on man's health and the ecosystem at large when man is but a unit of this ecosystem.

Take the situation in Nigeria for instance where most of the environmental challenges are to a very large extent caused by man and his direct activities towards the environment. A typical Nigerian will see a drainage and will dump his waste on the drainage which in most cases leads to flooding. Another scenario is where man will build his house on natural water ways blocking the water way in the process or is it the vandalization of pipelines by hungry youth or the illegal exploration of crude oil that in most cases leads to oil spillage that at the end will contaminate the streams and rivers around such areas or the indiscriminate exploitation of natural resources found in the environment without considering the implication of such activities on the environment or thinking about the impact of their activities on the future generation. This will lead us to the various causes of environmental problems.

The Nigerian Environmental Study Action Team in their report of the various environmental challenges facing Nigeria in 1991, said that, our resources exploitation to improve our welfare has exacerbated the nation's environmental problems (1 and 2). The problem of satisfying our needs with our environmental resources and using our resources to satisfy the needs of other countries coupled with our selfishness, greed and irresponsible actions towards the environment are responsible for a number of environmental problems ranging from pollution, deforestation, biological diversity loss, waste dumping/management, flooding, gas flaring among others (1 and 2).

Basically here, the critical problem is that, the assumption that man has dominion over the ecosystem and whatever is found in the ecosystem is available at no cost with absorptive capacity and for this reasons he degrades and abused the environment without realizing the immediate and future implication, man has therefore, brought whatever is happening presently to himself and the future generation.

\subsection{Causes Of Environmental Problems}

\subsubsection{Pollution}

Pollution is the process which renders the environment unclean and unsafe. Pollution affects water, land, air and the biosphere thereby constituting the worst and the most pervasive man-made hazards. To buttress this point further, Noibi said that, the remote cause of environmental problem is from human source and is the most pernicious type in agriculture, urban centres, industries, nuclear reactors and the petroleum industries are the worst source (12). 
The reason for this position is not farfetched since pollution is generated from many sources; it is easily the most widespread cause of environmental problem affecting mankind today and beyond. Pollution come in various forms like water, air, land and noise but in whatever form pollution comes, it is caused by man.

\subsubsection{Waste Dumping}

Another cause of environmental problem is toxic material or other harmful compound that have found their way into African countries especially Togo, Niger, Nigeria amongst others. These wastes contains element that are known to be poisonous at abnormally high concentration. Such elements and chemicals includes, arsenic, cadmium, mercury, lead, selenium, uranium and other radioactive elements. This uncontrolled and illegal dumping of hazardous wastes into our oceans, rivers and in landfills in unsuspecting very poor third world countries has cause a lot of havoc to the environment. A typical example was in 1987 - 1988 when five ship loads of Italian toxic wastes comprising ten thousand barrels of assorted poison were piled up in the yard of a farmer in Koko port in Delta State. Half of the barrels have begun to leak and was causing serious environmental hazard in the community before the Nigerian government were able to trace the ship that dump this waste to Italy. It was after vehement protest from the Nigerian government that almost cause the break-off of diplomatic ties and the out-cry from the international communities that now dawn on the Italian government to come and evacuate the hazardous waste from Koko port.

\subsubsection{Gas Flaring}

A gas flare alternatively known as a flare stack is a gas combustion device used in industrial plants such as petroleum refineries, chemical plants, natural gas processing plants as well as at oil or gas production sites having oil wells, gas wells, offshore oil and gas rigs.

Gas flaring at many oil and gas production sites protects against the dangers of overpressuring industrial plant equipment. Such unwanted gases like cfc, carbon-monoxide and other harmful gases are release into the atmosphere and this gases destroy the ozone layer that serve as a shield between the sun and earth. By destroying the ozone layer, the ultra violet radiation from the sun will come directly to earth and this will cause global warming which in turn will lead to melting of glaciers and polar ice caps, flooding coastal areas, shift in rainfall pattern, creating more droughts and severe tropical storms amongst other deadly effects on the environment.

\subsubsection{Deforestation}

Deforestation is the clearance or clearing of a forest or stand of trees where the land is thereafter converted to a non-forest use. A typical example is conversion of forest land to farms, ranches, urban development, timber and industrial purposes. It is estimated that about 3.8 million hectares of rainforest land are degraded. This abuse will become a threat at the long run when the rainforest is left exposed and bare. The major impact of deforestation to the environment includes erosion, landslides, inability of the forest to regulate the world's climate by absorbing carbon-dioxide and returning water to the atmosphere through transpiration etc.

\subsubsection{Loss of Biodiversity}


Human actions toward the environment is leading to the extinction of species and habitats. The ecosystem which took millions years to grow and develop are in danger when any species population is decimating through the activities of man. If we continue in this manner, our future generation will come to meet an ecosystem where some of the major species have gone extinct and this will not be two palatable. The future generation will only get to read about these species in books which is not ideal.

\subsection{Justice as Fairness}

Justice as a principle of natural law and as a gauge of humanity is nothing new. Plato holds that justice is the sole regulating principle of social life. This means that, justice is the foundation of any society and the hub around which it revolves. For Aristotle, he theorized that no society can stand which is not founded upon justice. This implies that justice is the surest foundation on which every society is anchored.

Justice there can be said to be a virtue which characterize an individual's life but is better exhibited in the intra-human and inter-human relationships where it is supposed to regulate all the human relationship within the society. Justice in this sense to buttress the point further comes in either moral, social or economical perspective in respect to our noncontemporaries.

John Rawls has two conception of justice running side by side. The first is formal justice which according to him is the impartial and consistent administration of laws and institutions. The formal principle of justice is a criterion which uses a generalization under which is embedded a rational principle (58). The application of this principle of justice is a theorized general principle which applies to every generation in the society without cases of special privileged considerations.

One of the prominent features of formal justice is that it is administered impartially and consistently with the institutional norms of the society to which it is fitted and as such, contemporaries and non-contemporaries have equal right thus, it is only just for any generation to be treated justly since such norms have already been laid down or instituted.

The second is substantive or material principle of justice. This primarily serves to make for inadequacies of the formal principle resulting from its general nature (Rawls, 58). What this means is that substantive principle gives specific criteria for administering justice in the practical society. It has a practical function through which it has been referred to as the actual principle of justice. This means that, the substantive principle of justice deals with the definite criteria for such allocation outlined.

Our major concern with justice as the foundation for any society or generation will have to do with substantive principle of justice which is a matter of the content of the laws not just with how they are administered. It is in the consideration of the substance of justice that John Rawls discusses fairness as the fundamental principle. An example of fairness or the absence of it can be shown in the way natural resources can be managed so as to enable the generations yet unborn enjoy the same natural resources the present generation is enjoying. When the natural resources are managed appropriately in any given society and in such a way that the non-contemporaries are taken into consideration, it will definitely spark up a feeling of belonging and patriotism between both generations.

It is pertinent to note here that, patriotism sparked up by justice in any society is very essential to the unique feeling of belonging or the feeling that the generation before or after has the future generation at heart. To this end, the importance of justice as a good feature or 
foundation of any society cannot be overemphasized since it is morally just and right to protect and preserve the resources found on the environment for the use of the future generation instead of abusing and regarding the environment.

It stands to reason therefore, that, this present generation have a moral duty or are obligated to protect, preserve and conserve the environment for the future generation. It is only morally just that this generation do that.

\section{Discussion}

\subsection{The Concept of Intergenerational Justice}

One possible working definition of intergenerational justice might be based on the principle of equality, understanding the term to mean that it would be unjust to treat something that is homogenous and of the same worth in a different manner. If this is the case, the future generation should as a matter of morality possess the same rights like the present generation.

Our constitution states that, before the law, all people are equal. This approach is consistent with other connotations of the world justice. Gender justice for instance means the sexes should the races should be treated equally. It therefore follows that, if we then regard all generations as equal, then a preliminary definition for intergenerational justice might be. No generation should be deliberately favoured or disadvantaged over another.

For those that will want to argue that the future generation are non-human and that the resources available should be used as the present generation deems it fit without considering them; it is pertinent to note that, the rights of the future generation have already been referred to in a number of international instruments such as the conventions of protection of the world cultural and national heritage (UNESCO, 1972), the Rio Declaration (1992), the Resolution of the UN General Assembly relating to the protection of the global climate adopted since 1990 and the Declaration on the Responsibilities of the Present Generation towards Future Generation (UNESCO, 1997) (See connect, 9).

Going by the afore-mentioned therefore, intergenerational justice is the most important theory supporting the argument explaining why nature and the environment should be protected for the future generation. Since the earliest days of the environmental movement, the rights and interests of future generations have invoked in argumentative discourse and as the environmental situations continue to unfold, philosophers and environmentalist are forced to redefined the scope of our moral obligation. There is no doubt in our minds that, the present is to a large and great extent living at the expense of the future generation. This is most evident when we consider the energy issue for instance, we all know as the following statement confirms that; fossil fuel is non-renewable.. every barrel of oil and ton of coal that we burn is forever lost for use by future generation; every mountain mined and wilderness developed in the search for coal and oil is also lost for the future. Secondly, "Combustion of fossil fuel and illegal activities by miners will continue to lump billions of tons of carbon dioxide into the atmosphere (Ugorji, 72). The question here is what are our duties? If any, is it to preserve and conserve the natural resources for the future generation and minimize risk to them?

These facts were perhaps not known and this questions never asked within the context of traditional theories of environmental ethics but today, we can easily see the consequences of the decision and actions of the present generation on the future generation. Not just our use 
of energy, natural resources but our population policy has ethical implications for the future people. To accommodate this fact; environmental philosophers have tended to review the notion of moral duty in order to make it include responsibilities of the present generation to the future generations. The purpose of this shift according to Jardins is called "anthropomorphic extensionism" and it is to give the future generations moral standing (109).

The question by some philosophers about the basis for granting rights to people who do not yet exist when raised can be answered that they are part of our moral community. What is a moral community one may ask? Moral Community can be seen as the community of all those who have the world as their common patrimony with duties to preserve it and rights to be sustained by it. It is a community of predecessors and successors in the one world in which we live. This type of community can be liken to the traditional African understanding of community which includes the ancestors, the living dead, the living and the unborn as bonded together with duties and rights in the mother earth. This African kind of community has the future generation at heart and whatever is done is the present, the unborn are always considered.

But in reality it is not the case. It has become glaringly clear that we are stealing from the future generation for the sake of present economic gains, selfishness, irresponsibility and greed. This selfish action by the present generation is surely a crime against future generations. The future generations deserve nothing less from us than our full compassion and our every effort to ensure them a sustainable future. It is our duty and obligation to take care of the environment for the future generation and this is what Immanuel Kant advocate in his categorical imperative where he states that we should act as if the maxim of our actions were to become through our will a universal law. This simply means that whatever we do to the environment we should consider the future generation because justice is universal and it cut across generations.

\subsection{A Synopsis of Kant's Categorical Imperative}

Immanuel Kant was a German philosopher whose teaching has influence his contemporaries and is still very much relevant in this present period. He was a renowned philosopher that contributed immensely to the development of philosophy especially in ethics.

Kant's ethical theory is founded upon the concept of the goodwill and whatever is extraneous to will falls outside the domain of morality. According to him, nothing can possibly be concerned in the world or even outside if it which can be called good with qualification except a "Goodwill" (310). What this simply means is that, the Goodwill is intrinsically good. There is no way a goodwill can be corrupted.

Kant did not just based his ethical theory on the concept of the goodwill. He talked about the categorical imperative. This is also called the imperative of morality. It is a moral command which is binding upon a person under any aid all situations as an end in itself and not subject to the hypothetical conditions seeking some particular desired end. Kant writes that "Now all imperatives command either hypothetically or categorically, the former represent the practical necessity of a possible action as means of something else that is willed (or atleast which one might possibly will). The categorical imperative would be that which represented an action as necessary of itself without reference to another end that is objectively necessary (Wolffe, 213). What this means is the categorical imperative which is the imperative we will be looking at declares an action to be binding in itself without reference to any purpose or end beyond itself. 
Going further, Wolffe explained that, the categorical imperative is conceived as the fundamental principle determining which possible principle can be respectively valid for the decisions of our will as such (213) when we say it is our duty to do something or refrain from doing it, we manifestly have in mind such categorical demand or such an objectively valid principle.

Having started the obvious, it is pertinent therefore to state the various varieties of Kant's categorical imperative, but in this work, it is the first and the second imperative that will be utilized in this paper:

1. The formula of the law of nature: This state that we should act as if the maxim of your action were to become through your will a universal law of nature.

2. The formula of end itself: Act in such a way that you always treat humanity, whether in your own person or in the person of any other, never simply as a means but always at the same time as an end.

3. The formula of autonomy: So act that your will can regard itself at the same time as making universal law through its maxims.

4. The formula of the kingdom of ends: So act as if you were through your maxims a law making member of a kingdom of ends.

From the above, the various categorical imperative constitute moral commands which everyone is duty bound to obey irrespective of the particular situation or circumstances facing him. This means that, a person must will to obey the moral laws without exception, a type of right is right and must be done even when the situation is at the extreme or let justice be done though the heavens will fall.

According to Elijah, O. John, from such position Kant maintains that, the parameter for moral standard is the principle of universalization (150). This simply means that, the test to determine morally right actions from morally wrong actions is the maxim of the action. By this maxim of the action, Kant means its underlying principle which in this case is an attempt to universalize it.

What is important to note here is that, in acting from a sense of duty or obligation, the individual must ask the question; "would I will that the maxim of my action become a universal law? Or will it be okay if everybody in a similar situation I find myself act or perform a similar action or take the same decision I took? For Kant, if the answer to the question is affirmative, that means the action is morally right and it also means that, the individual is acting from the sense of duty. On the other hand, if the action is negative, it means that the action is morally wrong and this means that, the individual is acting from inclination.

What I really want us to understand here is simply that, Kant's moral command or categorical imperative prescribe a duty for everyone to obey. There is no room for exception. It is universal that whatever is right for one person to do is right for all and whatever is wrong for one person is wrong for all people. This will bring us to out next sub topic and which will argue that indeed the present generation owe the future generation the duty and obligation to protect, conserve and preserve the environment for them.

\subsection{An Appraisal of Environmental Degradation from the Perspective of Kant's First and 2nd Rule of Categorical Imperative}


Applying Kant's categorical imperative to the present situation concerning the way and manner the present generation is abusing the environment, it is indeed an injustice to the future generation. Because of this present generation attitude towards the environment, the future generation will suffer a lot from actions of this generation if urgent and immediate measures are not taken to check this trend of abusing and degrading the environment.

If the generation before this present generation have abused the environment in this manner, what we are experiencing could have been more. Stories and news of hurricanes, cyclone, tsunami, flooding, acid rain, sun stroke amongst others are the common features that is being painted or experienced in this present generation and it is the activities of this present generation that caused the above situation where lives and properties worth billions of dollars have been lost due to our attitude towards the environment and our activities in using the natural resources found in the environment.

Kant's maxim that can be likened to the golden rule says "act only on that maxim whereby you can at the same time will that it should become a universal law" simply means that, if our irresponsible, greedy and selfish attitude towards the environment should become a universal law, can we as a nation of the future generation accept it if the answer is positive, then our selfish attitude towards the environment is morally right but if we cannot accept it as people of the future generation, then we should stop being selfish and change our attitude towards the utilization of the natural resources by not abusing it. We should only take the quantity we need and should be able to preserve the rest of the resources for the future generation.

In seeing ourselves as the future generation and our present actions and activities are not too wonderful towards the environment, we should make it a duty to preserve and conserve the environment for the future generation. It should become our burden and obligation to make sure that, we have an attitudinal change towards majorly our activities in the environment. It is only when we have been able to achieve this that the Kant's categorical imperative will make sense or properly utilized. Thus, the present generation should do everything humanly possible to take care of the environment for the future generation in as much as they will not like to suffer whatever will happen to the future generation to happen to them now. It is indeed their duty and obligation to protect the environment for the future generation.

\section{Conclusion}

Kant's categorical imperative is a moral law binding on all so that what is right for one man is right for all humanity. In as much as there is going to be another generation after this present generation and as we know that the future generation are going to be humans being and not robots or machines; it therefore follows that this generation owe the future generation the duty and obligation to protect the environment for their use. There is no need beating about or around the bush. It is their fundamental right as humans and it is the duty of this generation to see to it that the environment is not abused or degraded in any way again.

Structures should be put in place and a radical exposure of the magnitude of our present generations action on the environment should be exposed so that, when we see the effect of our individual actions and activities on the environment and what it implies, it will go a long way to change our attitude and mentality towards how we use and utilize the environment. The exposure can come in the way of video exposure where everyone will get to 
Budapest International Research and Critics Institute-Journal (BIRCI-Journal)

Volume I, No 3, October 2018, Page: 373-382

e-ISSN: 2615-3076(Online), p-ISSN: 2615-1715(Print)

www.birci-journal.com

emails; birci.journal@gmail.com

birci.journal.org@gmail.com

see the effect of our little activities on the environment and the repercussions that comes with such activities.

\section{References}

Abraham, C. The Language of Cities. Chicago: Equinox Books. 1971.

Ajake, A. O. \& Eja, E. I. Environment and Tourism: Principles and Practice. A monograph. 2017.

Barcalow, E. Moral Philosophy: Theories and Issues. California: Wadsworth Publishing Company. 1994.

Elijah, O. J. The substance of Ethics. Uyo: Scholars Press. 2005.

Federal Environmental Protection Agency (1992). Supplement to Critical Gazette Extraordinary. No. 13: PP. 179, Lagos.

Govier, T. What Should We Do About Future People: In Moral Issues. (Ed.) Jan Naneson. New York: Oxford University Press. 1983

Jardins, J. R. D. Environmental Ethics: An Introduction to Environmental Philosophy. California: Wadsworth Publishers. 1993.

Kant, I. Groundworks to the Metaphysics of Moral. Trans. By Paon, H. J. New York: Harper and Row Publisher, 1964.

Nicholson, M. The New Environmental Age. Cambridge: Cambridge University Press. 1987.

Nigerian Environmental Study/Action Team. Nigeria's threatened Environment: A Natural Profile. Ibadan. 1991.

Noibi, S. Y. "Population, Resources and Pollution: In Noibi, S. Y. and Rawal, M. T. (ed) Readings in Environmental Education. Lagos: Refied Nigeria Ltd. 1991.

Ozumba, G. O. A Course Text on Ethics. Lagos: Obaroh and Ogbinaka Publishers. 2001.

Rawls, J. A Theory of Justice. Oxford: Oxford University Press. 1971.

See Connect: A Publication by UNESCO International Science, Technology and Environmental Education. Newsletter. Vol. xxix, No. 3 - 4. 2004.

See Development in Law: International Environmental Law. 104 Harvard Law Review. Vol. $1 ; 1991$.

United State of America Conference of Catholic Bishops, Renewing the Earth: An Invitation to reflection and action on the Environment in light of Catholic Social Teaching. Nov. 14th, 1991. Cited in Ugorji, L. T. Sustaining the Environment.

Weiss, E. B. In Fairness of Future Generation International Law: Common Patrimony and Intergenerational Equality. New York: United Nation University Press. 1989.

Wolffe, P. Modern Studies in Philosophy (ed): Kant a collection of critical essay. London: Macmillan Press. 1968. 